\title{
PRINCIPLES INFLUENCING ADHERENCE TO TIME MANAGEMENT IN CONSTRUCTION PROJECT IN GOMBE STATE, NORTH EASTERN NIGERIA
}

\author{
Suleiman Shehu \\ Master Student in Project Management \\ Abubakar Tafawa Balewa University Bauchi-Nigeria, \\ Technical Officer in Civil Engineering Department \\ Nigerian Railway Corporation \\ Dr. Abdullahi Yusuf Waziri \\ Lecturer Department of Quantity Surveying \\ Abubakar Tafawa Balewa University Bauchi-Nigeria
}

Abstract- In this 21st century the issue of timely completion of project has become the business of every stakeholder in the construction industry. Nigeria is one of the fastest developing countries in the world; the construction industry is playing a vital role in its economic emancipation. Previous researchers have deliberated more on the causes of delay and yet there is paucity of information on the principles of time management. This study therefore examined the principles influencing adherence to time management in construction project in Gombe state, North-Eastern Nigeria. The study adopted a survey research method, where questionnaire was distributed through stratified random sampling to 88 personnel of the client, consulting and contracting organizations involved in construction project in Gombe state, Nigeria. While 62 questionnaires were duly completed, returned and found suitable for analysis, questionnaire administration attains $\mathbf{7 0 . 4 5 \%}$ response rate. Data obtained were analyzed using SPSS version 22, analysis were done in descriptive statistics and using non parametric test using Kendall's coefficient of concordance to establish the level of importance of sample factors and rank their mean scores according to their importance index. Findings revealed that effective communication and teamwork with (6.37 mean score); effective planning (6.10 mean score); Monitoring, controlling and evaluation of project work (6.10 mean score); Identification of purpose (5.84 mean score) and effective involvement of stakeholders with (5.41 mean score) were identified as the top most important principles influencing time management adherence in construction project in Nigeria. Therefore, it is recommended that effective adherence with the principles of time management identified in this study

\author{
Dr. Abdullahi Nafiu Zadawa \\ Lecturer Department of Quantity Surveying \\ Abubakar Tafawa Balewa University Bauchi-Nigeria
}

\author{
Rabiu Shehu \\ Quality Control Officer \\ Bilaad Realty Abuja-Nigeria
}

by all stakeholders in a construction project will go a long way to reduce the adverse effect associated with timeoverrun by ensuring timely completion of construction project in Nigeria.

Keywords - Principles, Time management, Time-overrun, Construction Project

\section{INTRODUCTION}

Nigeria is one of the fastest developing countries in the world; the construction industry is playing a vital role in its economic emancipation. It also forms one of the bases upon which the populace can assess the performance of the government. In this 21 st century the issue of timely completion of construction project has become the business of every stakeholder in the construction industry. The client is most affected by delay or time overrun which might affect his initial budget and plan usage of project upon completion etc. to the contractors and consultants provided everything remain the same, their failure to deliver the project on schedule will adversely affect their reputation in future. A research conducted by the Chartered institute of Building (CIOB) has indicated that the quality of time-management on construction projects is generally poor (CIOB, 2008). The research also indicates that Projects that suffer from disputes about delay also suffer from poor time control and too many projects suffer from delayed completion. Ahmed et al. (2003), found out that delay happen in every construction project and the magnitude of these delays varies considerably from project to project. Some projects are only behind schedule by a period range of one month to a maximum of over twelve months as the case may be. Previous researchers in the field of time and its management have deliberated more on the causes of delay 


\section{International Journal of Engineering Applied Sciences and Technology, 2019 \\ Vol. 4, Issue 5, ISSN No. 2455-2143, Pages 349-353 \\ Published Online September 2019 in IJEAST (http://www.ijeast.com)}

in completion of project, only few were able to assemble mitigating measures and yet there is paucity of information on the principles influencing timely completion of project in Nigeria. The afore-mentioned scenarios forms the bases upon which this study is undertaken in order to fill the gap by examining principles influencing adherence to time management in construction project in Gombe State, North Eastern Nigeria and the objectives are to: identify principles influencing adherence to timely completion of project in Gombe State, Nigeria and to evaluate the identified principles in order of their importance.

\section{LITERATURE REVIEW}

Project time management includes the processes required to accomplish timely completion of the project PMI (2013). Time management is a process of managing time according to the requirements of different assignments and activities with the goal of ensuring organizational success and maximizing benefits by utilizing, saving and not wasting time or energy (Sahito \& Vaisanen, 2017). Time overrun can be defined as late completion of works as compared to the planned schedule or contract schedule Memon, AbdulRahman and AbdulAzis (2012). A contract delay has adverse effects on both the owner and contractor (either in the form of lost revenues or extra expenses) and it often raises the contentious issue of delay responsibility, which may result in conflicts that frequently reach the courts Abass (2006). Basically, there are no well documented principles solely applicable to construction project time management. Though, several researchers in the field of project and management have reported some applicable procedures for effective management of construction project in their various studies which includes: planning- Sahito and Vaisanen (2017), Amiri et al. (2014), Amade et al. (2015), Murithi et al.(2017); Identification of purpose- Eshaghieh and Eslami (2015), Bahadori et al. (2015), Odumeru (2013); Prioritization- Eshaghieh and Eslami (2015), Bahadori et al. (2015); Delegation- Eshaghieh and Eslami (2015), Tracy(2013), Khamaksorn (2016), Scheduling- Sahito and Vaisanen (2017), Amiri et al. (2014); Accountability- Adeyinka (2012), Acharya et al. (2004), Bivins (2006); Minimizing time wasters- Sahito and Vaisanen (2017), Eshaghieh and Eslami (2015); Monitoring, controlling, evaluation- Murithi et al. (2017), Memon et al. (2012), Ofori (2013), Amade et al. (2015); Communication, teamwork- Lohiya (2010), UNDP (2009), Ayodeji et al. (2017) and Involvement of Stakeholders- Bizon-Gorecka and Gorecki (2017), Amade et al. (2015). same upper left corner of the $2 \mathrm{nd}$, 3rd inferior wavelet transform.

\section{METHODOLOGY}

Basically, in order to achieve the set objectives of the study, an extensive literature review was undertaken to know more on time and management issues in construction project. A quantitative method was adopted using structured questionnaire survey designed to gather information regarding principles influencing timely completion of project in Nigeria. A 6-point likert scale (Completely Disagree-1, Mostly Disagree-2, Slightly Disagree-3, Slightly Agree-4, Mostly Agree-5, Completely Agree-6) was used and stratified random sampling was adopted to understand the perception of 53 personnel working for the client, consulting and contracting organizations involved in handling construction projects in Federal University Kashere and Federal College of Education (Technical) all in Gombe state, Nigeria and of which 44 correctly completed questionnaires were returned. The participants were surveyed regarding their willingness to adhere with the principles of time management proposed. The data obtained was analyzed using SPSS version 22 statistical software using descriptive statistics and Kendall's coefficient of concordance to establish the level of importance of the sample factors and were ranked according to their importance index. The factors with the highest mean score values are considered the most important principles to be used to ensure adherence to time management in construction project in Nigeria.

\section{RESULTS AND ANALYSIS}

A total of 88 questionnaires were distributed randomly amongst experienced and academically qualified personnel representing the client, consultants and contractors in Gombe state, North Eastern Nigeria. 62 responses were received and the data were analyzed. The questionnaire administration attains $70.45 \%$ response rate. The findings of study are presented and discussed below.

\subsection{Demographics of Respondents}

The results of the survey shows that the participants have the academic qualifications, working experienced and they have experienced extension in project delivery time as depicted in Table 1.

Table 1, shows that most of the respondents that participated in the survey were representing the client $38.7 \%$, while those working for the contractors and consultants have $32.3 \%$ and $29.0 \%$ respectively. Also, more than $70 \%$ of the respondents have more than 6 years working experience in construction project work and virtually all the respondents had obtained first degree which shows that the respondents were competent enough and capable to participate in the survey. Also, more than $97 \%$ of the respondents have experience time overrun with 1-12 months representing more than $70 \%$ accounting for the most prevalent rate. 
Table 1: Demographic Characteristics of Respondents

\begin{tabular}{lll}
\hline Category of working organization & $\mathbf{N}$ & $\mathbf{\%}$ \\
Client & 24 & 38.7 \\
Consultant & 18 & 29.0 \\
Contractors & 20 & 32.3 \\
& 62 & 100.0 \\
Years of working experience & $\mathbf{N}$ & $\%$ \\
0-5 years & 15 & 24.2 \\
6-10 years & 23 & 37.1 \\
11-15 years & 16 & 25.8 \\
More than 15 years & 8 & 12.9 \\
& 62 & 100.0 \\
Academic qualification & $\mathbf{N}$ & $\mathbf{\%}$ \\
NCE / ND & 2 & 3.2 \\
Degree/HND & 38 & 61.3 \\
Masters/PGD & 19 & 30.6 \\
PhD & 3 & 4.8 \\
& 62 & 100.0 \\
Length of extension of time & $\mathbf{N}$ & $\%$ \\
0 months & 1 & 1.6 \\
1-6 months & 26 & 41.9 \\
6-12 months & 23 & 37.1 \\
12-18 months & 5 & 8.1 \\
more than 18 months & 7 & 11.3 \\
Total & 62 & 100.0 \\
\hline
\end{tabular}

Table 2, shows that $86.2 \%$ of the respondents were in agreement that effective communication and teamwork will influence timely completion of project as against $13.8 \%$ that disagreed. $75 \%$ of respondents have positive agreement each on effective planning and accountability, integrity \& responsibilities while $25 \%$ disagree, this is so because planning without implementation or adherence to plans is like nothing has been done. The respondents have positive agreement of $81.8 \%$ each for identification of purpose; prioritization of project activities and monitoring, controlling and evaluation of project as principles influencing timely completion of project. $77.3 \%$ of respondent have identified effective delegation of responsibilities; effective daily/weekly scheduling of activities and involvement of stakeholders as principles influencing timely completion of project unlike $22.7 \%$ that disagreed. $72.8 \%$ are in agreement with minimizing and managing time wasters as against $27.3 \%$ that disagreed. In this study $78.62 \%$ of respondents are in support with the factors identified as capable of influencing timely completion of project while $21.38 \%$ were in disagreement. As such, all the principles are accepted because they are above $70 \%$ using the principle of equality of $50 \%$ bench mark for acceptance or rejection.

Source: Authors' Field Survey (2019)

Table 2: Percentage of Respondents' Identification with the Principles of Time Management

\begin{tabular}{|c|c|c|c|c|c|c|c|c|c|}
\hline \multirow{2}{*}{$\begin{array}{l}\text { Principles influencing Project Time } \\
\text { Management Adherence }\end{array}$} & \multicolumn{3}{|c|}{ Disagreement (\%) } & \multicolumn{4}{|c|}{ Agreement (\%) } & \multirow[b]{2}{*}{ Sum } & \multirow[b]{2}{*}{ Grand total } \\
\hline & 1 & 2 & 3 & Sum & 4 & 5 & 6 & & \\
\hline -Effective planning & & 6.8 & 18.2 & 25.0 & 9.1 & 38.6 & 27.3 & 75.0 & 100 \\
\hline -Identification of purpose (setting goals) & & 4.6 & 13.6 & 18.2 & 25 & 43.2 & 13.6 & 81.8 & 100 \\
\hline -Effective prioritization of activities & 4.5 & 2.3 & 11.4 & 18.2 & 29.5 & 34.1 & 18.2 & 81.8 & 100 \\
\hline $\begin{array}{l}\text {-Effective delegation of } \\
\text { activities/responsibilities }\end{array}$ & 4.5 & 2.3 & 15.9 & 22.7 & 22.7 & 45.5 & 9.1 & 77.3 & 100 \\
\hline $\begin{array}{l}\text {-Effective daily/weekly scheduling } \\
\text {-Ensuring accountability, integrity \& }\end{array}$ & & 9.1 & 13.6 & 22.7 & 22.7 & 36.4 & 18.2 & 77.3 & 100 \\
\hline responsibilities & 9.1 & 2.3 & 13.6 & 20.0 & 22.7 & 31.8 & 20.5 & 75.0 & 100 \\
\hline -Minimization \& managing time wasters & 9.1 & 6.8 & 11.4 & 27.3 & 45.5 & 20.4 & 6.8 & 72.7 & 100 \\
\hline $\begin{array}{l}\text {-Monitoring, controlling and evaluation of } \\
\text { project }\end{array}$ & 2.3 & 6.8 & 9.1 & 18.2 & 22.7 & 38.6 & 20.5 & 81.8 & 100 \\
\hline -Effective communication \& teamwork & & 11.5 & 2.3 & 13.8 & 24.9 & 34 & 27.3 & 86.2 & 100 \\
\hline -Effective involvement of stakeholders & & 6.8 & 15.9 & 22.7 & 40.9 & 25 & 11.4 & 77.3 & 100 \\
\hline Total & & & & 21.38 & & & & 78.62 & 100 \\
\hline
\end{tabular}

Source: Authors' Field Survey (2019) 


\section{International Journal of Engineering Applied Sciences and Technology, 2019 \\ Vol. 4, Issue 5, ISSN No. 2455-2143, Pages 349-353 \\ Published Online September 2019 in IJEAST (http://www.ijeast.com)}

Table 3, shows the respondents scores on the principles of time management. The study shows that effective communication and teamwork was ranked $1^{\text {st }}$ with mean score of 6.37. Effective planning; Monitoring, controlling and evaluation of project were ranked $2^{\text {nd }}$ with mean scores of 6.10 each. Identification of purpose came $4^{\text {th }}$ with 5.84 mean score and Effective involvement of stakeholders was ranked $5^{\text {th }}$ with corresponding mean score 5.41. However, the least ranked principles were Effective prioritization $9^{\text {th }}$ and Minimizing and managing time wasters $10^{\text {th }}$ having mean scores of 5.14 and 4.10 respectively.

Table 3: Mean score rank of principles of time management

\begin{tabular}{|c|c|c|c|}
\hline $\mathbf{S} / \mathbf{n}$ & $\begin{array}{l}\text { Principles influencing time } \\
\text { management Adherence }\end{array}$ & $\begin{array}{l}\text { Mean } \\
\text { Score }\end{array}$ & Ranking \\
\hline a. & $\begin{array}{l}\text { Effective communication \& } \\
\text { teamwork }\end{array}$ & 6.37 & $1^{\text {st }}$ \\
\hline b. & Effective planning & 6.10 & $2^{\text {nd }}$ \\
\hline c. & $\begin{array}{l}\text { Monitoring, controlling and } \\
\text { evaluation of project }\end{array}$ & 6.10 & $2^{\text {nd }}$ \\
\hline d. & $\begin{array}{l}\text { Identification of purpose } \\
\text { (setting goals) }\end{array}$ & 5.84 & $4^{\text {th }}$ \\
\hline e. & $\begin{array}{l}\text { Effective involvement of } \\
\text { stakeholders }\end{array}$ & 5.41 & $5^{\text {th }}$ \\
\hline f. & $\begin{array}{l}\text { Ensuring accountability, } \\
\text { integrity \& responsibilities }\end{array}$ & 5.36 & $6^{\text {th }}$ \\
\hline g. & $\begin{array}{l}\text { Effective daily/weekly } \\
\text { scheduling }\end{array}$ & 5.30 & $7^{\text {th }}$ \\
\hline h. & $\begin{array}{l}\text { Effective delegation of } \\
\text { activities/responsibilities }\end{array}$ & 5.27 & $8^{\text {th }}$ \\
\hline i. & $\begin{array}{l}\text { Effective prioritization of } \\
\text { activities }\end{array}$ & 5.14 & $9^{\text {th }}$ \\
\hline j. & $\begin{array}{l}\text { Minimization \& managing } \\
\text { time wasters }\end{array}$ & 4.10 & $10^{\text {th }}$ \\
\hline
\end{tabular}

Source: Authors' Field Survey (2019)

\section{DISCUSSION}

Basically, various researchers in the field of construction project and management in their various studies have corroborate the importance of some of the principles influencing time management adherence identified in this study such as: UNDP (2009), Good communication improves clarity on expectations, roles and responsibilities, as well as information on progress and performance and this clarity helps to ensure optimum use of resources. Amade et al. (2015), in their studies conclude that Adequate Planning account for $29 \%$ variation in causing the success of construction projects. Also, Ayodeji et al. (2017) in their studies, find out that adequate planning and monitoring project were ranked as the most important factors influencing project performance. Murithi et al. (2017), in their studies of factors influencing timely completion of project in Kenya, find out that more than $80 \%$ of the respondents were in agreement with high ratings that project planning impact on timely project completion on schedule.

The implication of these results is that adherence with the principles of time management especially effective communication and teamwork, effective planning, monitoring and evaluation, and engagement of stakeholders with a combine mean scores of 29.82 representing $54.88 \%$ in principles will influence timely delivery of construction project in North Eastern Nigeria.

\section{CONCLUSION}

This study aimed at examining the principles influencing adherence to time management in construction project in Gombe State, North Eastern Nigeria and the objectives are to: identify principles influencing adherence to timely completion of construction project in Gombe State, Nigeria and to evaluate the identified principles in order of their importance. The findings revealed that the top most important principles of time management adherence are: effective communication and teamwork; effective planning; identification of purpose; monitoring, controlling and evaluation of project work and Effective involvement of stakeholders. In conclusion the aim of this study has been achieved. Therefore, it is recommended that effective adherence with the principles of time management identified in this study by all stakeholders in a construction project will go a long way to reduce the adverse effect associated time-overrun by ensuring timely completion of construction project in Nigeria.

\subsection{Limitations and Future Directions for Research}

This study was carried in a limited time, the sample size of 53 might not be too convincing and it was carried out in only two institutions in Gombe State, which is one out of six states in North Eastern Nigeria. As such, there is need to carry out similar study in other part of Nigeria with more respondents, especially in other areas related to time management.

\section{REFERENCE}

[1] Abass, M. I. (2006). Causes and Effects of Delays in ACEH Construction Industry. Unpublished Master Thesis: Universiti Teknologi Malaysia.

[2] Acharya, N. K., Kim, S., \& Lee, Y. (2004). Factors Affecting Timely Completion of Construction Projects. Proceedings of the Fifth Asia Pacific Industrial Engineering and Management Systems Conference. APEMS.

[3] Adeyinka, A. (2012). Effective Time Management For High Performance In An Organization: Case Of Lasaco Assurance Plc. seinajoki-finland: An unpublished 


\section{International Journal of Engineering Applied Sciences and Technology, 2019 \\ Vol. 4, Issue 5, ISSN No. 2455-2143, Pages 349-353 \\ Published Online September 2019 in IJEAST (http://www.ijeast.com)}

Barchelor Project, Seinajoki University of Applied Science, Finland.

[4] Ahmed, S.M., Azhar, S., Kappagntula, P. and Gollapudil, D. (2003). Delays In Construction: A Brief Study Of The Florida Construction. Proceedings of the 39th Annual ASC.

[5] Amade, B., Ubani, E. C., Omajeh, E. O.-M., \& Njoku, U. A. (2015). Critical Success Factors for Public Sector Construction Project Delivery: A Case of Owerri, Imo State. International Journal of Research in Management, Science \& Technology (E-ISSN: 2321-3264), 3(1)11-21.

[6] Amiri, Z., Ghobadian, M., \& Mirzaei, A. (2014). The Study Of Time Management Factors And Their Influences On Productivity. Kuwait chapter of Arabian journal of business management review, 3 :10a.

[7] Ayodeji , O., Eseohe, A., Opeyemi, J., Ebenezer, B., Amusan, L., \& Abisola, O. (2017). Project Mnagement A Panacea to Improving The Performance of Construction Projects In Ogun State, Nigeria. International Journal of Civil Engineering and Technology, http://www.iaeme.com/IJCIET.

[8] Bahadori, M., Salesi , M., Ravangard , R., Hosseini, S., Raadabadi, M., Dana, A. H., et al. (2015). Prioritization of Factors Affecting Time Management among Health Managers. International Journal of Travel Medicine and Global Health, 3(4):159-164.

[9] Bivins, T. H. (2006). "Responsibility and Accountability" in Ethics In Public Relations: Responsible Advocacy. ousand 399 Oaks, London-UK: SAGE Publications, Inc.

[10] Bizon-Gorecka, J., \& Gorecki, J. (2017). Influence of Selected Stakeholders of Construction Investment Projects on The Course of Project. IOP Conf. Series: Materials Science and Engineering 245 (2017) 072018 doi:10.1088/1757-899X/245/7/072018 (pp.1-7). IOP Publishing.

[11] Chin, L. S., \& Abdulhamid, A. (2015). The Practice Of Time Management On Construction Project. The 5th international conference of euro asia civil engineering forum (EACEF-5) (pp. 32-39). Procedia Engineering 125.

[12] CIOB (Chartered Institute of Building). (2008). Managing The Risk Of Delayed Completion In The 21st Century. Chartered industry of building (CIOB).

[13] Eshaghieh, A. E., \& Eslami, S. (2015). The Effect of Time Management on Human Resources' Productivity Social Security Organization of Yazd. J. Appl. Environ. Biol. Sci., 5(11S)69-79.

[14] Khamaksorn, A. (2016). Project Management Knowledge and Skills for Construction Industry. International Conference on Civil, Architecture and
Sustainable Development (pp. 93-97). London(UK): (CASD-2016) Dec. 1-2, 2016.

[15] Lohiya, G. (2010). Team Building in Project Management Practice in the UAE Construction Industry. IPEDR, Singapore, 31-35.

[16] Memon, A. H., Abdul Rahman, I., \& Abdul Azis, A. (2012). Time and Cost Perfomance in Costruction Projects in Southern and Cenrtal Regions of Penisular Malaysia. International Journal of Advances in Applied Sciences (IJAAS), 1(1):45-52.

[17] Murithi, S. H., Makokha, E. N., \& Otieno, C. (2017). Factors Affecting Timely Completion of Public Construction Projects in Trans-Nzoia County. International Journal of Scientific and Research Publications, ISSN 2250-3153, 7(4): 404 - 434.

[18] Odumeru, J. A. (2013). Effective Time Mnagement. Singaporean Journal of business Economics, and management studies, 1(1):9 -17.

[19] Ofori, D. F. (2013). Project Management Practices and Critical Success Factors-A Developing Country Perspective. International Journal of Business and Management, Published by Canadian Center of Science and Education, 8(21)14-31.

[20] Project management institude (PMI BOK). (2013). A guide to project management body of knowledge :5th Ed. penncylvania-USA: Project management instititude inc.

[21] Sahito, Z., \& Vaisanen, P. (2017). Effect Of Time Management On Job Satisfaction And Motivation Of Teacher Educators: A Narative Analysis. International Journal of Higher Education, 6 (2) 213-224.

[22] Tracy, B. (2013). Time Management. Newyork(USA): American Mnagement Association.

[23] United Nation Development Programme (UNDP). (2009). Hand Book on Planning, Monitoring and Evaluating For Development Results: United Nation Development Programme. NewYork: one united nations plaza/www.undp.org/eo/handbook. 